\title{
DIE OU TESTAMENT OOR MENSEREGTE
}

\section{J. L. Helberg}

Hierdie voordrag bepaal hom tot basiese riglyne oor die regte van mense in die Ou Testament en gaan nie op besonderhede in nie.

Die term "menseregte" is belas omdat dit veral gebruik is in kringe wat 'n onaanvaarbare opvatting het van die mens se verhouding tot God. Volgens hierdie kringe is die mens 'n soort gelyke van God eerder as 'n afhanklike, 'n vennoot van God en vriend van God eerder as 'n kind van God. Die Bybel leer egter 'n heeltemal ander verhouding tussen God en mens.

\section{God is vrymagtig}

God is die absolute soewereine skepper en regeerder oor hemel en aarde. Reeds die heel eerste vers van die Skrif benadruk dit: "In die begin het God die hemel en die aarde geskep" (Gen. 1:1). Die psalms is vol van hierdie soewereiniteit van God: "Die hemel getuig van die mag van God, die uitspansel mak die werk van sy hande bekend" (Ps. 19:1); "Die aarde en alles wat daarop is, die wêreld en dié wat daar woon, alles behoort aan die Here" (Ps. 24:2). Psalm 150 is een groot lofsang op die grootheid en almag van God. Almal en alles word opgeroep om Hom te prys. Ook die profete verkondig hierdie almag van God. "Ek is die Here, Ek het alles geskep" (Jes. $44: 24$ ); Ek is die Here, dit is my Naam, die eer wat My toekom, gee Ek aan geen ander nie" (Jes. 42:8); Ek is die Here, julle heilige God, die Skepper van Israel, julle Koning" (Jes. $43: 15$ ).

God eis absolute onderworpenheid van die mens, onvoorwaardelike gehoorsaamheid. Daarom mog die mens in die tuin van Eden nie van die kennisboom geëet het nie. Dit was om die eenvoudige rede dat God dit verbied het. God eis dat die mens hom met verstand en al onvoorwaardelik aan God onderwerp. Daar is geen sprake van menseregte in die sin van bedingingsregte teenoor God nie.

Tog, wat gesê is, gee wel 'n ware beeld van die mens se verhouding tot God, maar nie die volle beeld nie. Die mens se verhouding tot God behels nie bloot gehoorsaamheid nie. God is nie 'n blote Eiser nie en staan nie in 'n blote juridiese verhouding tot die mens nie. God géé, daarom eis Hy. Ook in die Paradys. God voorsien oorvloedig in die mens se stoflike behoeftes: die mens mag van al die ander bome van die tuin eet. God voorsien ook in die mens se geestelike behoeftes in die wye sin van die woord. God het self gesê dit is nie goed dat die mens alleen is nie en het vir hom 'n lewensmaat voorsien. Die onvoorwaardelike eis om nie van die kennisboom te eet nie, val nie uit die lug nie en kom nie van 'n onbekende God nie. Die bevel kom inteendeel van die God teenoor wie die mens vervul behoort te wees met dankbaarheid vir die stoflike en geestelike dinge wat hy so ryklik ontvang het.

Ek kom hierop weer terug. 


\section{Die mens se identiteit en roeping}

Laat ons ondertussen eers weer kyk na die begrip "menseregte". Die begrip "mens" klink so wyd, dit sluit gelowiges en ongelowiges in. 'n Mens sou dalk kon vra of die begrip "menseregte" nie eerder Babels is as Bybels nie. Hierop lui die antwoord. Wanneer die Bybel met Israel praat, gaan hy ook so ver terug as die skepping: nie net tot by die tyd van Dawid, die verbondsvolk se goue eeu nie, nie net tot by die uittog uit Egipte, die verbondsvolk se volksgeboorte nie, nie net tot by Abraham, die tyd van verbondsluiting waarin die verbondsverhouding met die volk wat uit Abraham gebore sou word, in vooruitsig gestel is nie. Die Bybel gaan terug tot by die skepping van die mens. Die mens is belangrik as God se besondere skepsel. $\mathrm{Hy}$ is na die beeld van God geskep; hy is die verteenwoordiger van God. Tegelykertyd beteken die mens se beeldskap van God dat hy 'n kind van God is maar dat daar tog ook 'n groot verskil tussen God en mens is, dié van Skepper en skepsel. Die mens het 'n hoë waarde. Dit het hy egter nie uit homself nie maar slegs in soverre hy verteenwoordiger van God is, beeld, skadubeeld van God.

Die klemtoon val nie op die mens se passiewe staat, status of identiteit nie, maar op sy taak, sy opdrag, sy roeping. God sê: "Kom Ons maak die mens as ons verteenwoordiger, ons beeld, sodat hy kan heers ..." (1:26). Psalm 8 teken die tweërlei hoedanigheid van die mens pragtig: sy kleinheid, nietigheid en tog sy grootheid as regeerder van die skepping: "As ek $u$ hemel aanskou, die werk van $u$ vingers, die maan en die sterre waaraan $U$ 'n plek gegee het, wat is die mens dan dat $U$ aan hom dink, die mensekind dat $U$ na hom omsien? $U$ het hom net ' $n$ bietjie minder as 'n hemelse wese gemaak en hom met aansien en eer gekroon. U laat hom heers oor die werk van $u$ hande, $U$ het alles aan hom onderwerp ..." (Ps. 8:4-7). Die mens ontvang hierdie heerskappy en aansien nie tot sy eie eer nie, maar tot eer van God. So moet die mens sy taak uitvoer. Hierdie psalm begin en eindig dan ook met lof, nie aan die mens nie, maar aan God: "Here, ons Here, hoe wonderbaar is u Naam oor die hele aarde!" Die klemtoon val nie op die mense se regte nie maar op sy taak en roeping, voorvloeiend uit die baie wat hy ontvang.

Die Heidelbergse Kategismus lê ook die klemtoon daar: my enigste troos in lewe en in sterwe is: "Dat ek met liggaam en siel, in lewe en in sterwe, nie aan myself nie, maar aan my getroue Saligmaker Jesus Christus toebehoort... daarom ... maak Hy my van harte gewillig en bereid om verder vir Hom te lewe" (vraag 1). Ook in antwoord op die vraag "waarom word jy 'n christen genoem?" lê die Kategismus die klemtoon nie op die status of regte nie maar op die roeping: "Omdat ek deur die geloof 'n lid van Christus is en daardeur deel het aan sy salwing, sodat ek sy Naam kan bely, myself as 'n lewende dankoffer aan Hom kan toewy, met 'n vrye en goeie gewete in hierdie lewe teen die sonde en die duiwel kan stry..." (vraag 32 ).

Die mens as sondige en verloste wese

Genesis $6: 5-7$ teken 'n ander kant van die mens, die mens so an- 
ders as wat hy geskape is, die mens ná die sondeval. Die mens is deur en deur verdorwe en hy bedink sy lewe lank net slegte dinge. $\mathrm{Hy}$ verdien om vernietig te word. Daarom laat die Here die sondvloed oor die aarde kom. Genesis 8:21 sê die verloste mensdom ná die sondvloed is net so verdorwe. Ook elders in die Ou Testament word die mens so beskrywe (vgl. 1 Kon. $8: 46$; Job. 14:4; Ps. $14: 2$, 3; 51:7; $143: 23$; Spr. $20: 9$; Pred. $7: 20$; Jer. 13:23; $17: 9$ Eseg. $36: 26)$. Die Heidelbergse Kategismus vat dit so saam: " $\mathrm{Ek}$ is van nature geneig om God en my naaste te haat" (vraag 5 ).

Die vraag kom na vore of hierdie verdorwe mens nog enige regte het. Of het hy alles verloor? Dit is duidelik dat hy teenoor God op geen regte kan aanspraak maak nie aangesien hy alles verbeur het. Tog is God nog genadig oor sy gevalle skepsel en het menslike logika hier nie die laaste woord nie (vgl. ook Jes. 55:8 e.v.). Ek kom hierop later terug en wys ondertussen daarop dat God wel aan mense regte gee wat beskerm moet word. Dit blyk uit sy woorde aan Kain: "Die bloed van jou broer roep van die aarde af na My" (Gen. $4: 10$ ). God het 'n verbond met Noag gesluit waardeur Hy orde op die aarde vaslê. God eis van 'n mens rekenskap oor die lewe van sy medemens, enige medemens. Die rede daaroor: God het die mens gemaak as sy verteenwoordiger, sy beeld (Gen. $9: 5,6)$. In die Bybel en so ook die Kategismus se skildering van die verdorwenheid van die mens val die nadruk nie op die onbekeerdes se slegtigheid in teenstelling tot ons as gelowiges nie, maar op ons almal se sondigheid: ons geneigdheid om selfsugtig te wees teenoor ander en nie hulle belange te bevorder en dit wat aan hulle volgens God se gebod toekom, te gee nie.

Laat ons verder kyk na nog 'n tekening van die mens, behalwe dat hy beeld van God is en dat hy 'n gevalle en verdorwe sondaar is. God het vir die mens verlossing bewerk. Dit kom reeds in die Paradys tot uiting, maar veral in die roeping van Abraham en die verbond wat God met hom sy nageslag sluit. Net soos by Abraham impliseer die verbond vir die volk ' $n$ indiwidueel persoonlike verhouding met God. Dit sluit 'n indiwidualistiese verhouding uit, maar ook 'n sosialistiese. Die gelowige se verhouding tot God draai nie net om een mens alleen nie maar stel hom in 'n breëre verband en benadruk sy verantwoordelikheid, taak en roeping. Hy verloor egter ook nie so persoonlikheid binne 'n groter geheel en struktuur of massa nie, maar het 'n volle indiwidualiteit. Hierdie tweërlei hoedanigheid van die verbond waarin die mens as enkeling sowel as verantwoordelike deel van 'n groter gemeenskap leef, is van groot belang vir die siening van menseregte.

Die neiging om God in 'n geïsoleerde middelpunt te plaas

Israel het as verbondsvolk die ernstige fout gemaak om vas te haak by hulle identiteit as verbondsvolk in die sin van hulle status as verbondsvolk, in plaas van gedryf te word deur hulle taak, verantwoordelikheid en roeping. Daarom skiet hulle ver te kort as gelowiges. Hulle vertroetel die gedagte dat hulle die verbondsvolk is. Hulle voel as hulle dit maar glo, is alles in orde, as hulle maar in God 
glo en God in die middelpunt plaas. Dit het hulle inderdaad gedoen. Hulle het vasgehou aan hulle belydenisse oor God, hulle het offerandes gebring, godsdienstige feeste gehou en tot God gebid. Maar hulle het God in 'n geïsoleerde middelpunt geplaas. Hulle het Hom nie waarlik gedien as God wat groter is as die erediens nie, God wat oor die alledaagse lewe regeer, God wat Skepper is van die hele aarde, koning van alle mense.

Die profete wys daarop dat ondanks Israel se diens aan God daar nie reg geskied nie, dat die armes en ander hulpeloses verdruk word. Volgens Jesaja spreek God die volk soos volg aan: "Wat het Ek aan julle baie offers? vra die Here. Ek is sat van die brandoffers van ramme en die vet van voerbeeste... As julle kom om voor My te verskyn, wie het julle gevra om my voorhowe te kom vertrap? ... Nuwemaansfeeste, sabbatsvierings, die uitroep van feesdae: Ek verdra nie feesviering met onreg saam nie ... Leer om weer goed te doen, sorg dat daar reg geskied, gaan die verdrukker teë. Laat reg geskied aan die weeskinders, behartig die regsaak van die weduwees" (Jes. 1:11, 12,13,17). Die profeet Jeremia stel dit so: "Julle sê... Dit is die Here se tempel, dit is die Here se tempel, dit is die Here se tempel!" Maak liewers julle lewe en julle dade reg. Doen aan mekaar wat reg is, moenie vreemdelinge, weeskinders en weduwees onreg aandoen nie, moenie mense onskuldig om die lewe bring in hierdie land nie" (Jer. 7:4-6). Die profeet Amos spreek die mense van Samaria soos volg aan: "Luister na hierdie woord, julle deur wie die swakkes verdruk en die armes mishandel word... kom na Bet-El toe as julle sonde wil doen, na Gilgal toe as julle nog meer sonde wil doen. Bring julle offers vroegmóre, julle tiendes op die derde dag..." (Am. 4:1-4). "Gee pad voor My met die rumoer van jou gesing; Ek wil nie jou harpmusiek hoor nie! Maar laat die reg aanrol soos watergolwe, soos 'n standhoudende stroom" (Am. $5: 23,24)$.

Die profeet Miga getuig soos volg teen sy volk se godsdiensbeoefening: "Wat sal ek saamvat as ek na die Here toe gaan, as ek voor die hoë God gaan kniel? Moet ek met offers na Hom toe gaan, met jaaroud kalwers? Sal die Here duisende ramme aanvaar saam met tien duisende offers van olie? Moet ek my eersgeborene offer vir my sonde, hom wat uit my liggaam kom, vir my oortreding? Mens, die Here het jou bekend gemaak wat goed is: Hy vra van jou dat jy reg sal laat geskied, dat iy liefde en trou sal bewys, dat iy bedagsaam sal lewe voor jou God" (Miga 6:6-8). Die aangehaalde gedeeltes wys hoe skerp die profete hulle uitspreek teen 'n verbondsvolk wat God wel dien in die erediens maar nie reg teenoor mense laat geskied nie.

Nie net teenoor lede van die verbondsvolk moet reg geskied nie, maar teenoor alle mense. Die mensdom is afstammelinge van een mensepaar en daarom een groot familie. Dit word ook by die roeping van Abraham en sy afsondering om ' $n$ besondere nasie te wees, beklemtoon. In Abraham sal al die nasies van die aarde geseën word, sê die Here (Gen. $12: 1-3$; vgl. ook Rut, Jona, Jes. 2, 42, 49). 
Daarom het God ook bepalings gegee dat vreemdelinge goed behandel moet word (Lev. $19: 33$ ) en het die profete Israel ernstig vermaan omdat hulle in gebreke gebly het om dit te doen. Jesus sê dan ook: "As julle getrouheid aan die wet nie meer inhou as dié van die Skrifgeleerdes en die Farisiërs nie, sal julle nooit in die koninkryk van God ingaan nie" (Matt. 5:20). Jesus eis dat die gelowiges volmaak moet wees soos die hemelse Vader volmaak is. "Hy laat immers sy son opkom oor slegtes en goeies, en Hy laat reën oor dié wat reg doen en oor dié wat verkeerd doen" (Matt. $5: 45,48$ ).

Die tien gebooie bevat duidelike bepalings oor hoe daar teenoor die naaste reg moet geskied. Dit staan in die vyfde tot tiende gebod opgeteken en dit rus op die gebooie wat die regte verhouding tot God bepaal. Die tien gebooie laat geen opening daarvoor dat God gedien kan word maar die verhouding tot die naaste en die reg doen aan die naaste daargelaat kan word nie. Dit rus alles in God se verlossende genade en die verbondsverhouding waarin $\mathrm{Hy}$ sy volk tot Hom gestel het: "Ek is die Here jou God, wat jou uit Egipte, uit die plek van slawerny, bevry het" (Eks. 20:2). Die gesindheid waarin die gebooie onderhou moet word, is dié om God lief te hê met hart en siel en jou naaste soos jouself (Deut. 6:4, 5; Lev. $19: 18$ ).

Verantwoordelikhede eerder as eise

Uit wat oor die profete en die tien gebooie gesê is, blyk dat die woord eis dat daar aan mense reg moet geskied. Mense kan hulle op die tien gebooie beroep ter wille van hulle reg. Hulle kan hulle byvoorbeeld daarop beroep dat hulle God moet dien (eerste gebod) en dat hulle Hom op besondere manier op die rusdag moet dien (vierde gebod). Hulle kan hulle daarop beroep dat hulle nie onverhoord en ligvaardig veroordeel moet word nie (negende gebod). 'n Mens sou kon sê dat mense sekere regte van God ontvang waarop hulle hulle teenoor ander kan beroep. Maar dit is belangrik dat sowel by dic profete as by die tien gebooie die aanbieding en inkleding nie so is dat vir die mense gesê word wat hulle regte is nie. Die profete roep nie die verontregtes op om op te kom vir hulle regte nie. God se eis konsentreer op ' $n$ mens se plig en roeping teenoor ander mense en hulle regte.

'n Ander kenmerk wat belangrik is by die tien gebooie is die negatiewe vorm waarin die gebooie oor die algemeen gegiet is: "jy mag nie..." Die vorm sê eintlik: jy wil gaan moord pleeg, jy wil oneerlik wees, jy wil jou naaste veronreg, maar jy mag nie. Die vorm van die tien gebooie sê dus dat ons almal geneig is om nie ons naaste tot sy reg te laat kom nie. Die vorm van die tien gebooie is dus te gelykertyd 'n oproep tot bekering van die verkeerde weg en gesindheid, gearriveerdheid, ook in verband met regte van mense. Die vorm van die wet waarsku dus teen selftevredenheid by die gelowiges, en teen verbondsegoïsme. Uit die voorgaande blyk dus dat die tien gebooie besonder positief is in verband met die bevordering van die regte van mense. Die gebooie gaan veel wver en veel dieper as om namens 'n mens reate vir jouself op te eis. Die regte word gewaarborg deur die verantwoordelikheid van een mens teenoor ' $n$ 
ander te stel. So word tegelykertyd selfgesentreerdheid en selfsug afgesny. Dit geld vir die een wie se regte in gedrang is sowel as by die een wat daaraan iets kan doen. Die klemtoon val op elkeen se positiewe roeping. Almal word op dieselfde vlak gestel. Daar word nie 'n groeps- of soort klasverskil gemaak van gewers en ontvangers nie.

Die Skrif waarsku teen 'n gesindheid wat daarop ingestel is om jou regte op te eis eerder as om te konsentreer op jou verantwoordelikhede en roeping. Die Skrif wys dat so 'n selfgesentreerde lewe hand aan hand loop met selfsug. Hierdie selfgesentreerde gesindheid kom voor by Lameg uit die geslag van Kain. Hy sing vir sy vrouens: "Ek maak 'n man dood as hy my wond, 'n seun as hy my seermaak. Kain sal sewe maal gewreek word, Lameg sewe en sewentig maal" (Gen. $4: 23,24$ ). Die selfgesentreerde lewe ontsier ook gelowiges se lewe. Hiervan is Jakob 'n voorbeeld. Reeds voor sy geboorte het die Here aan sy ma Rebekka bekend gemaak dat hy en sy geslag die bevoorregtes sal wees bo Esau (Gen. $25: 23$ ). Jakob is egter so selfgesentreerd dat hy as't ware steel wat syne is, soos Esau se seën. Daarvoor moes hy duur betaal en selfs baie lank uit sy land pad gee. Eers twintig jaar later, net voor sy ontmoeting met Esau, het sy lewe 'n wending geneem by Pniël (Gen. 32). Daar het God vir Jakob laat verstaan dat hy met sy selfgesentreerde lewe en die stryd wat hy om sy regte teen mense stry, hom tog net in die afgrond stort. Jakob kom hier tot ' $n$ ander gesindheid: om sy belange veel meer in God se hand te lê en eerder te konsentreer op 'n dankbaarheidslewe in antwoord op die seën wat hy uit genade van God ontvang het.

Die tien gebooie wys ook dat die regte verhouding teenoor die naaste nie bloot ' $n$ saak van plig is nie. Die gebooie rus op die inleiding, soos reeds gestel is, en vloei voort uit die feit dat God sy volk verlos en uit die slawehuis uitgelei het. By 'n ware verbondskind vloei die regte optrede teenoor die naaste voort uit dankbaarheid teenoor God. Ons hoor in Lev. 19:33, 34: "Wanneer daar 'n vreemileling by julle in julle land woon, mag julle hom nie onderdruk nie. Julle moet hom soos 'n medeburger behandel en hom liefhê soos julleself. Julle was self ook vreemdelinge in Egipte. Ek is die Here julle God".

Die stoflike verlossing ingebed in die geestelike verlossing

God eis reg en geregtigheid. Dit het ook met die stoflike lewe te doen, selfs met die staatkundig-politieke lewe. Daar moet egter onthou word dat politieke bevryding in die Bybel ingebed is in geestelike verlossing. God vra in die eerste plek bekering en geloof in sy geregtigheid wat uit genade verlossing skenk, nie uit verdienste nie. Die Here vereis 'n lewe volgens sy gebooie, 'n lewe as lid van sy volk, sy gemeente. Stoflike belange is heeltemal ondergeskik hieraan. Abraham, Isak en Jakob moes hulle lewe lank vreemdelinge bly in die beloofde land. Die volk van God moes selfs bereid wees om lyding te verduur ter wille van Hom. Toe die Verlosser Jesus Christus kom, het dit vir Israel nie politieke bevryding gebring nie. Christus het Israel in die eerste plek opgeëis vir die diens van sy 
evangelie. Die Bybel bied dus geen grond vir 'n bevrydingsteologie nie. So 'n teologie maak of die hoofnadruk in die Bybel op politieke bevryding lê. Die Bybel bied ook geen grond vir 'n vryheidsteologie op 'n voortbestaansteologie nie. So 'n teologie maak asof die hoofnadruk in die Bybel op voortbestaan val, hetsy politiek hetsy anders.

God betoon veral genade aan die arme en hulpelose, dié mens wat nie op homself vertrou nie, maar homself diep afhanklik van God voel en op Hóm vertrou. Die Bybelse regverdige en arme vorm 'n sterk teenstelling met iemand wat selfgenoegsaam is. God is wel veral teenoor die armes en hulpeloses genadig en neem hulle saak op, maar Hy is nie partydig vir hulle nie. Hy keur ook nie partydigheid teenoor hulle goed nie. Inteendeel, $\mathrm{Hy}$ eis volle onpartydigheid wanneer daar in gedinge uitspraak gegee moet word: "Jy mag nie onregverdig wees in die regspraak nie: jy mag nie partydig wees vir dié wat geen aansien het nie of die vooraanstaande bevoordeel nie" (Lev. 19:15). Hierdie bepaling is van groot belang vir 'n gebalanseerde benadering van menseregte.

\section{Dieper as ' $n$ regsverhouding}

Die vraag kom op of 'n mens nie liewer van mense se voorregte in plaas van menseregte moet praat nie. In dié verband het ek reeds daarop gewys dat 'n mens volgens die tien gebooie wel regte teenoor ander mense het en dat hy hom in 'n regsgeding daarop sou kan beroep. Die psalmdigters beroep hulle dan ook inderdaad dikwels daarop dat God aan hulle reg moet verskaf teenoor hulle vvande, daar moet reg geskied aan die regverdige (vgl. bv. Ps. $4: 2 ; 17: 15$; $45: 5)$. Teenoor God het die mens in werklikheid geen aanspraak op reg nie maar is soos klei in die hand van die pottebakker. Dit staan God vry om met die mens te maak soos Hy wil. Dit kom duidelik uit in die geskiedenis van Job. Bowendien is die mens 'n sondige wese wat skuldig staan teenoor God. Tog is dit ook in die mens se verhouding tot God nie reg om van mense se voorregte te praat nie. Die Bybel gebrulk nie so 'n term nie. maar gooi die saak oor 'n ander boeg: geregtigheid deur die geloof in God se genare, toegerekende reg. As sondige wese kan die mens alleen uit God se genade leef. Hy moet daardie genade aanvaar, hy moet dit glo. Dan word dit hom as geregtigheid gereken: Hy word deur God beskou asof hy reg het op wat hy deur die geloof aanvaar, asof hy regverdig is.

Die verhouding tussen God en sy volk is dieper as 'n regsverhouding en kan nie met die gewone betekenis van geregtigheid of reg uitgedruk word nie. In die Bybel beroep die gelowige hom in sy verhouding tot God dan ook gewoonlik nie op die geregtigheid van God nie maar op God se liefde en trou. Dit is nie 'n regsgrond wat aangeroer word nie, maar 'n pleitgrond. Die laaste twee verse van die boek Klaagliedere is 'n aangrypende voorbeeld hiervan. Die pleitgrond wat daarin aangevoer word, vorm 'n sterk teenstelling met die onpervlakkige benadering vór die val van Jerusalem. Die vers lui: "Bekeer $U$ ons tot $U$, Here, dat ons bekeer kan wees, gee ons weer die bestaan van vroeër. Of het $U$ ons heeltemal verwerp? 
Is u toorn oor ons so groot?" Psalm $143: 1,2$ wys hoe 'n beroep op God se geregtigheid verstaan behoort te word. Dit is 'n beroep op God se trou, wat nie met sy gelowige na die gereg toe gaan nie, omdat die gelowige nie die toets sal kan deurstaan nie! " $U$ is getrou en regverdig, antwoord my tog! Moet tog nie 'n regsaak teen my begin nie, want iemand wat leef, is voor U regverdig nie!" Die mens staan nie bloot in 'n wetlike verhouding tot God nie maar in 'n kindskapsverhouding. Die mens kan weens sy sonde maar net om genade pleit by God; en hy kan ook vra dat God in sy genade ander mense daartoe moet bring om geregtigheid teenoor hom te beoefen.

\section{Gesindheid en konkretisering}

Die grondoorsaak en die heelmiddel vir mense se probleme word vandag dikwels in die samelewingstrukture self gesien. Alles word verwag van ' $n$ verandering van strukture. Dit word dan ook gesien as die hooftak van die kerk. Hierdie benadering verabsoluteer egter die samelewingstrukture en miskien die eintlike taak van die kerk. Tog moet ons nie die fout maak om te dink dat die strukture onbelangrik is en dat verandering nie noodsaaklik is nie. Die kerk se taak is wel veral om mense op te roep tot bekering, verandering van hart. Maar daar moet nie 'n teenstelling tussen verandering van hart en verandering van strukture gemaak word nie. Dit is net so verkeerd as om die twee te vereenselwig en om te dink dat verandering van strukture vanself verandering van harte meebring.

Die gelowiges moet in die lig van die tien gebooie strewe na 'n samelewingsbestel waarin die roeping ten opsigte van God en van die naaste so veel as moontlik tot sy reg kan kom.

Jesus Christus vat die wet en die profete, die eis van die Ou Testament, saam in die een groot gebod: om God lief te hê met 'n mens se hele hart, met jou hele siel en met al jou $\mathrm{krag}$, en jou naaste lief te hê soos jouself (Matt. $22: 37-40$ ). Liefde en geregtigheid moet dus onderskei maar nie geskei word nie. Liefde is die gesindheid waarin gehoorsaamheid of geregtigheid beoefen moet word - nie onpersoonlik en wetties nie, maar van harte. Liefde is egter nie net 'n gesindheid nie, maar kry gestalte in dade: die beoefening van reg en geregtigheid.

\section{Opsommend}

Afsluitend kan oor menseregte in die Ou Testament gesê word: Mense het regte. Die Skrif benader en stel dit egter nie so dat ons moet gaan sit en rekensomme oor ons regte moet maak nie. Die Skrif plaas die regte binne die raamwerk van ons verantwoordelikheid - ons s'n vir ander, en ander s'n vir ons. Die klemtoon val op ons taak, ons roeping. Menseregte word nie benader vanuit 'n standpunt van menslike eise vir regte nie, maar positief uit mense se verpliotinge om ander se regte te laat geld. Dit maak ons verantwoordelikheid des te groter, want dit is dus nie Bybels om terug te sit en te wag dat mense self vir hulle regte moet vra of opstaan nie.

Dit behoort nie moeilik te wees om ons verantwoordelikhede na te kom nie, want om vir ander se regte op te kom, is nie bloot 'n 


\section{In die Skriflig}

verpligting nie. God se eise word gestel binne die raamwerk van wat God aan ons gee, wat ons van God ontvang. Dit is dus iets wat die ware gelowige uit erkentlikheid en dankbaarheid teenoor God, wil doen. Wie waarlik uit die geloof leef, beskou die take nie bloot as verpligtinge nie maar sien dit as geleenthede, en hy gryp dit aan met geesdrif.

Tegelykertyd is dit so dat ons as sondige mense van nature geneig is om God en ons naaste te haat, om ons naaste se reg te misken. Daarom moet ons onsself en ons samelewing gedurig in die lig van die Woord daaroor oproep tot verantwoording en bekering, en waar nodig tot hervorming.

* Hierdie voordrag is gelewer voor die Gereformeerde Teologiese Vereniging te Pretoria op 4 Junie 1984.

GERAADPLEEGDE LITERATUUR

J. L. HELBERG: Die Here regeer. Openbaringslyn deur die Ou Testament2. Pretoria 1983.

J. L. HELBERG: Bybelse geregtigheid In: Afrikanerskap en Bybelse lig. Pretoria 1984.

REFORMED ECUMENICAL SYNOD: RES testimony on human rights. Grand Rapids, M'chigan 1983.

W. H. VELEMA: Discussie over de mensenrechten. Apeidoorn 1980. 